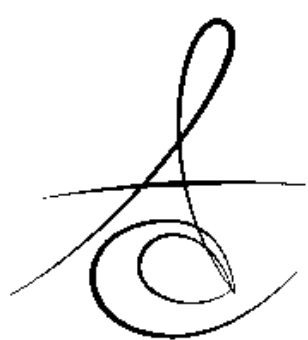

\section{SANTRAL DEV HÜCRELİ GRANÜLOMANIN İLİAK GREFT VE HAREKETLİ YER TUTUCU APAREY İLE REHABİLITTASYONU: OLGU SUNUMU\#"}

\section{REHABILITATION OF CENTRAL GIANT CELL GRANULOMA WITH ILIAC GREFT AND REMOVABLE SPACE MAINTAINER: CASE REPORT ${ }^{\#}$}

\author{
Yrd. Doç. Dr. İbrahim DAMLAR* \\ Arş. Gör. Dt. Saim YANIK** \\ Arş. Gör. Dt. Ahmet ALTAN* \\ Yrd.Doç.Dr.Zeki ARSLANOĞLU*** \\ Yrd. Doç. Dr. Cengiz ÇEVİK****
}

Makale Kodu/Article code: 1253

Makale Gönderilme tarihi: 01.08.2013

Kabul Tarihi: 03.10 .2013

\section{ÖZET}

Amaç: Santral dev hücreli granüloma sıklıkla mandibula ve maksillada lokalize olan, non-odontojenik patolojik bir lezyondur. Etiyolojisi tam olarak bilinmemektedir. Lezyonun cerrahi olarak uzaklaştırıması en çok uygulanan tedavi yöntemidir. Amacımız bu vakada santral dev hücreli granülomanın iliak greft ve hareketli yer tutucu aparey kullanılarak rehabilitasyonunu rapor etmektir.

Vaka raporu: 10 yaşındaki erkek hasta kliniğimize mandibula anterior sol bölgede şişlik şikayetiyle başvurdu. Alınan anamnezde, şikayetin olduğu bölgeye yaklaşık 1 yıl önce cerrahi bir müdahale yapıldığı, fakat şişliğin altı ay önce tekrar oluştuğu öğrenildi. Genel anestezi altında lezyon çıkartıldı. Mandibular sol santral, lateral, kanin ve birinci premolar dişler çekildi. Mandibulada oluşan defekt iliak greftle onarıldı. Çıkarılan kitlenin histopatolojik incelemesi yapıldı ve santral dev hücreli granülom tanısı konuldu. Operasyon sonrası yapılan 12 aylık takipte herhangi bir problemle karşılaşılmadı. Daha sonra hastaya hareketli yer tutucu bir aparey yapıldı.

Sonuç: Literatürde santral dev hücreli granülom gibi agresif lezyonların \%72 rekürens oranı olduğu görülmektedir. Rekürens gösteren vakalarda kortikostreoid enjeksiyonu, sistemik kalsitonin uygulaması gibi konservatif yöntemlerin başarısı kesin değildir. Cerrahi tedavi çene kemiklerinde major defektlere neden olabilir ve fasiyal konturu bozabilir. Böyle bir durumda defektin iliak greftle tamiri estetik problemleri çözecektir ve protezle rehabilitasyon imkanı sunacaktır.

Anahtar kelimeler: santral dev hücreli granüloma, iliak greft, hareketli yer tutucu

\section{ABSTRACT}

Purpose: Central giant cell granuloma is a nonodontogenic pathological lesion that usually located in the mandible and maxilla. The aetiology of giant cell granuloma is undefined. Surgical removal is the most commonly applied therapy. Our aim was to report rehabilitation of central giant cell granuloma with iliac graft and removable space maintainer.

Case Report: A 10-years-old child was referred to our clinic complaining of swelling in the mandibular anterior region. The parents of the patient were reported that a surgical operation was done in mandibular anterior region of the patient one year ago. They also reported that this lesion was recurred six months after first surgery. The recurred lesion was removed under general anesthesia, mandibular left central, lateral, canine and first premolar teeth were extracted. Iliac crest graft was harvested and fixed to the mandible. The histopathology report confirms the diagnosis of a central giant cell granuloma. The patient's postoperative 12 months follow-up exam was uneventful. The patient was referred for removable space maintainer.

Conclusion: Aggressive lesions such as central giant cell granuloma observed $72 \%$ recurrence rate to the literature. Conservative methods such as corticosteroid injection, systemic calcitonin's success isn't definite on the recurred lesion. The surgical treatment may cause major defects in jaw bones and changes the facial contours, the repair of the defect with iliac bone graft was performed to solve aesthetic problems and facilitate the further prosthetic rehabilitation.

Key words: central giant cell granuloma, iliac crest graft, removable space maintainer

*Ağız-Diş ve Çene Cerrahisi A.D., Mustafa Kemal Üniversitesi, Diş Hekimliği Fakültesi, Hatay, Türkiye

**Ağız-Diş ve Çene Cerrahisi A.D., Gaziantep Üniversitesi, Diş Hekimliği Fakültesi, Gaziantep,Türkiye

***Pedodonti A.D., Mustafa Kemal Üniversitesi, Diş Hekimliği Fakültesi, Hatay, Türkiye

****Kulak Burun Boğaz A.D., Mustafa Kemal Üniversitesi, Tıp Fakültesi, Hatay, Türkiye

\# 18. Bass kongresi 25-28 Nisan 2013, Üsküp/Makedonya'da sözlü bildiri olarak sunulmuştur.

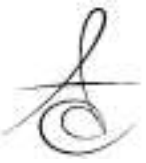




\section{GİRİş}

Santral dev hücreli granüloma (SDHG) kraniyofasiyal bölgede genellikle mandibula ve maksillada tutulum gösteren, non-odontojenik patolojik bir lezyondur. Bu benign durum sıklıkla 30 yaş altı bireylerde görülür ve kadınlardaki prevelansı daha yüksektir ${ }^{1}$. Ayrıca görülme oranı mandibulada maksilladan daha fazladır ${ }^{2-4}$. Etiyolojisi tam olarak bilinmemekle birlikte, kemiğin travma, inflamasyon ya da hemorajiye karşı lokal reperatif bir reaksiyonu şeklinde düşünülür ${ }^{5}$. SDHG'nın klinik davranışı asemptomatik, yavaş büyüyen bir şişlikten; ağrı, kortikal destrüksiyon, kök rezorbsiyonu ve rekürrensle karakterize agresif bir lezyona doğru çeşitli değişiklikler göstermektedir ${ }^{3,6,7}$. Radyolojik bulgular uniloküler veya multiloküler radyolusent ve farklı derecedeki kortikal ekspansiyondan oluşmaktadır ${ }^{4,7}$.

Lezyonun cerrahi olarak uzaklaştırılması en çok tercih edilen tedavi yöntemidir. Cerrahi yöntem küretajdan rezeksiyona çeşitlilik gösterir. SDHG kalsitoninin sistemik olarak günlük uygulanması ${ }^{8-11}$, kortikosteroidlerin lezyon içine enjeksiyonu ${ }^{12-14}$, radyasyon $^{15}$ ve subkütanöz interferon enjeksiyonu ${ }^{16}$ gibi konservatif metotlarla da tedavi edilebilir.

\section{OLGU SUNUMU}

10 yaşındaki erkek hasta kliniğimize mandibula anterior sol bölgede şişlik şikayetiyle başvurdu. Sistemik bir rahatsızlığı yoktu. Alınan anamnezde, şikayetin olduğu bölgeye yaklaşık 1 yıl önce cerrahi bir müdahale yapıldığı, fakat şişliğin tekrar oluştuğu öğrenildi. Klinik muayenenin ardından hastanın panoramik ve bilgisayarlı tomografi görüntüleri değerlendirildi. (Resim 1,2). Genel anestezi altında mukoperiosteal flep kaldırılıp lezyon çıkartıldı. Sol mandibular santral, lateral, kanin ve birinci premolar dişler çekildi. Operasyon sırasında lezyonun uzaklaştırılması ile mandibulada oluşan defekt fasiyal konturu bozacak büyüklükteydi ve hasta için estetik problem oluşturmaktaydı. Hastanın sağ anterior iliak krestinden alınan mono kortikal blok greft 2 mini vidayla mandibulaya sabitlendi (Resim 3,4). Flep primer olarak kapatıldı. Çıkarılan kitlenin histopatolojik incelemesi yapıldı. İncelemede düzenli dağıım gösteren multinükleer dev hücreler izlendi. Ayrıca mononükleer tipte iltihabi hücre ilfiltrasyonu görüldü ve santral dev hücreli granüloma tanısı konuldu.

Operasyon sonrası yapılan üç, altı ve oniki aylık takiplerde (Resim 5) herhangi bir problemle karşılaşılmadı. Hastadaki dişsiz bölgeye estetik, fonasyon ve beslenme problemleri nedeniyle protez yapılmaya karar verildi. Hastanın yaşı itibariyle, kemik gelişimi tamamlanmadığı için hareketli bir yer tutucu aparey yapıldı (Resim 6).

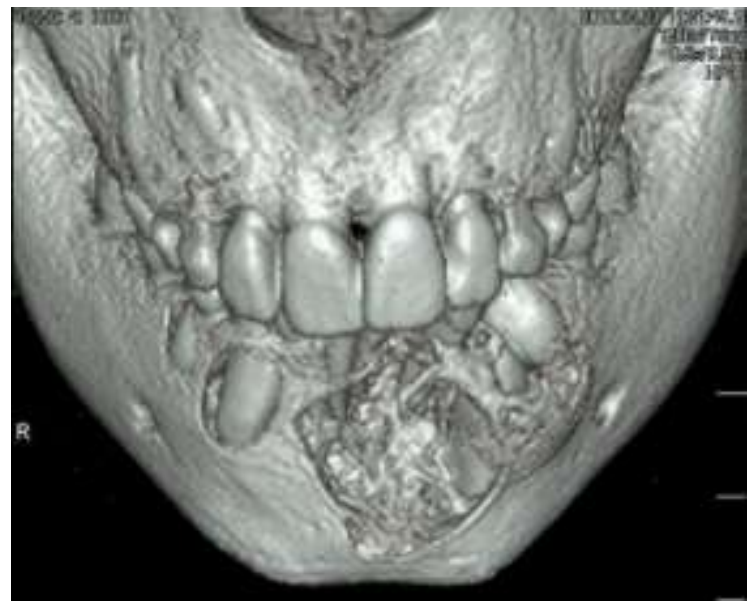

Resim 1. Operasyon öncesi 3D tomografik görünüm

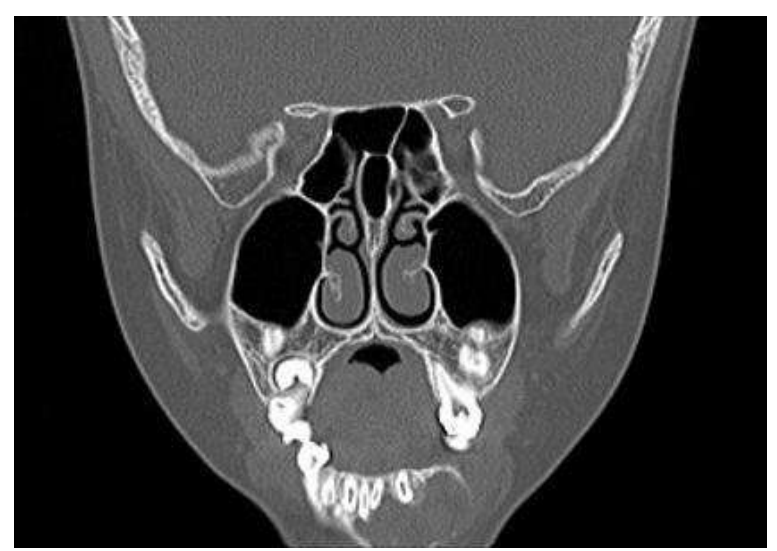

Resim 2. Lezyonun koronal tomografik görünümü 


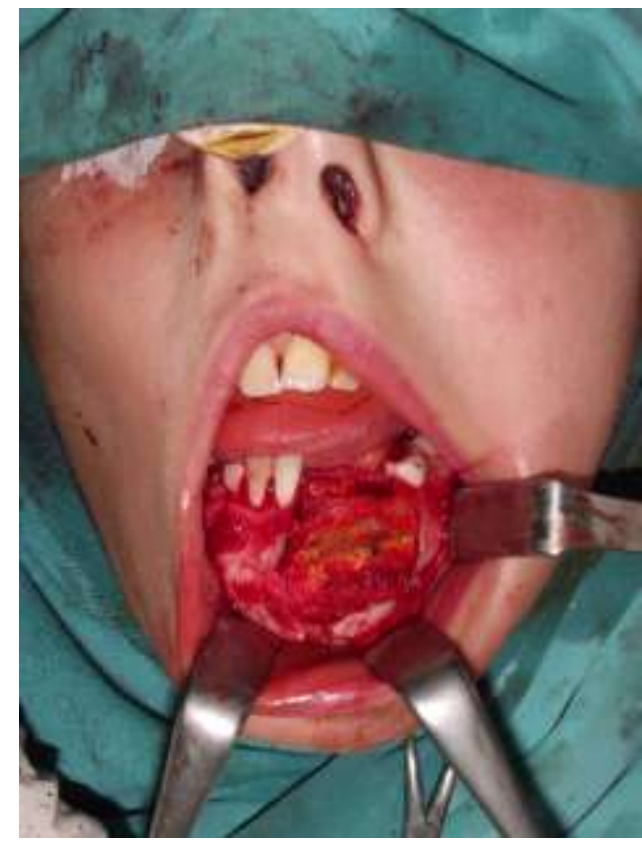

Resim 3. İliak greftin mini vidayla sabitlenmesi

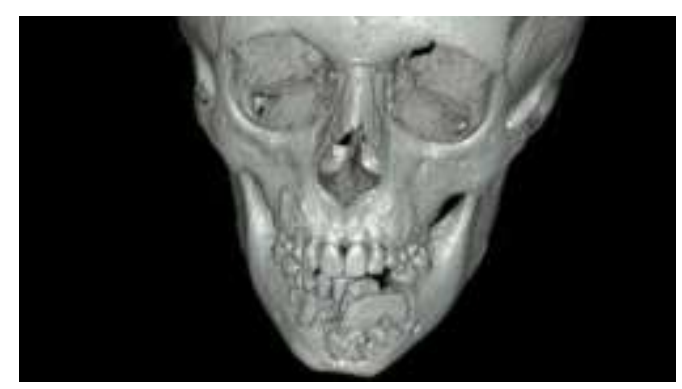

Resim 4. Post-operatif 3D tomografik görünüm

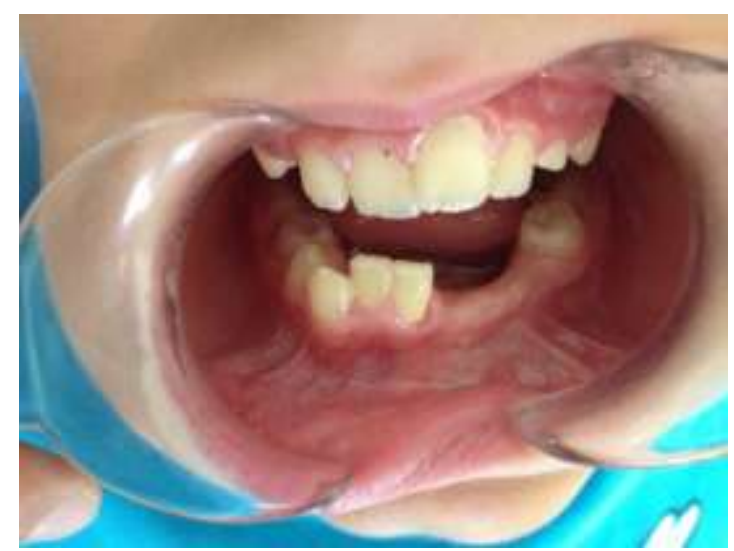

Resim 5. Post-operatif 12. Ay ağız içi görünüm

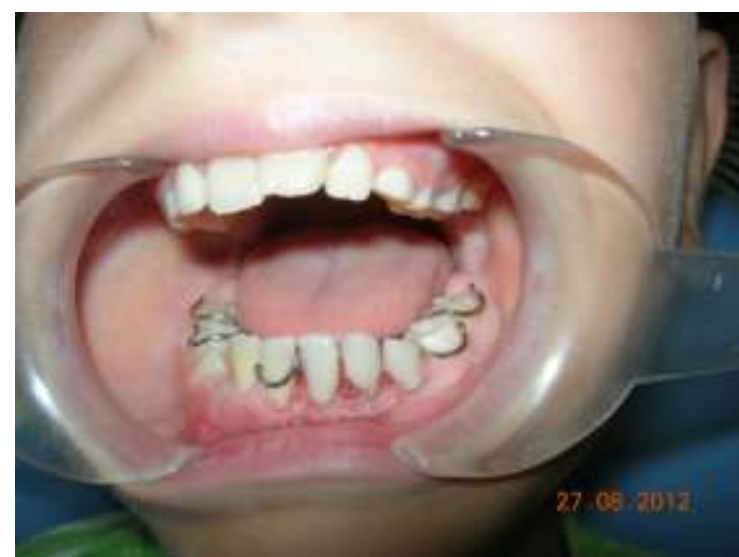

Resim 6. Hareketli yer tutucunun ağız içi görünümü

\section{TARTIŞMA}

Santral dev hücreli granüloma ağırlıklı olarak çocuklarda ve genç yetişkinlerde görülür. Kesin bir görülme yaşı belirlenememesine rağmen Whitaker ve Waldron $^{3}$ sundukları vakaların $\% 75^{\prime}$ inde bireylerin 30 yaş altı olduğunu bildirmişlerdir. Kaffe ve arkadaşları ${ }^{4}$ lezyonların \%60'ının 30 yaş altında görüldüğünü söylemişlerdir ve ortalama görülme yaşını 29.8 olarak belirtmişlerdir. Eisenbud ve arkadaşları ${ }^{15}$ ise yaş sınırını yükselterek vakalarının \%89'unun 50 yaş altı bireylerde görüldüğünü bildirmişlerdir. Sunduğumuz vakada hasta 10 yaşında çocuktu.

SDHG kadınlarda erkeklere göre 2:1 oranla daha fazla görülür ${ }^{3,17}$. Lezyon mandibulada maksillaya göre daha fazla tutulum gösterir ${ }^{2-4}$. Bazı yazarlar ${ }^{3,4,18}$ lezyonun mandibulada görülme oranını \%72 olarak belirtmişlerdir. Eisenbud ve arkadaşları ${ }^{15}$ ise bu oranın \%68 olduğunu söylemişlerdir.

SDHG'da her iki çene kemiğinde de anterior bölgenin daha fazla etkilendiği belirtilmektedir ${ }^{4,17,18}$. Maksillanın anatomik farklılıklarından dolayı maksillar SDHG'nın teşhis, tedavi ve prognozu mandibulada görülen SDHG'ya göre farklılık göstermektedir. Maksillanın süngerimsi yapısından dolayı lezyonun genişlemesi mandibulaya göre daha erken olmaktadır ${ }^{19}$. Maksillada lokalize SDHG vakalarında maksillar sinüs, orbita tabanı ve nasal fossa etkilenebilir. Olgu sunumumuzdaki hasta kliniğimize başvurduğunda mandibula anterior bölgede vestübül tarafa ekspansiyon gösteren şişlik mevcuttu.

Kaffe ve arkadaşları ${ }^{4}$ SDHG'nın radyolojik olarak iyi sınırlı veya sınırları düzgün olmayan uniloküler ve multiloküler görünüm sergileyebileceğini söylemiş-

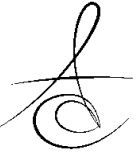


lerdir. Hastanın radyolojik muayenesinde multiloküler radyolusent bir görünümle karşılaşılmıştır.

Choung ve arkadaşları ${ }^{17}$ SDHG'nın agresif veya non-agresif olduğunun belirlenmesinde altı kriter belirlemişlerdir. Bu kriterler; ağrı, şişlik, dişlerin kökünde rezorpsiyon, rekürens, kortikal perforasyon ve büyüme oranıdır. De Lange ve Van den $A k k e{ }^{20}$ agresif lezyonların en çok genç hastalarda görüldüğünü belirtmişlerdir. 10 yaşındaki çocuk hasta kliniğimize başvurduğunda büyük boyutlarda şişlik gösteren bir lezyon mevcuttu. Alınan anamnezde bir yıl önce cerrahi müdahale uygulanmasına rağmen lezyonun tekrar oluştuğu öğrenildi. Agresif olduğu görülen bu durumun tedavi planlaması da buna göre yapıldı.

SDHG'da tedavi seçeneğinin belirlenmesinde; lezyonun agresif veya non-agresif davranış göstermesi, lokalizasyonu, boyutları ve radyolojik görünümü etkili olmaktadır. Cerrahi tedavi en çok uygulanan ve geleneksel olarak her zaman kabul gören bir yöntemdir. Bununla birlikte literatüre bakıldığında nasıl bir cerrahi yöntem uygulanacağı yönünde bir fikir birliği yoktur. Cerrahi yaklaşımlar en bloc rezeksiyondan daha konservatif bir tedavi olan küretaja değişiklik göstermektedir. Çeşitli yazarlar ${ }^{3,17,20}$ küretajla eksizyon yapılan hastalarda rekürrens oranının \%16'dan \%49'a değişiklik gösterdiğini belirtmişlerdir. Sunulan vakada lezyon nüks etmiş agresif bir lezyondu. Bu nedenle konservatif yöntemler yerine cerrahi tedavi tercih edildi ve marjinal rezeksiyon yapıldı.

Gelişim çağındaki çocuklarda agresif cerrahi yaklaşım diğer yaklaşımlara göre daha radikaldir. Onun yerine konservatif yöntemler tercih edilmektedir. Ancak lezyon içi steroid tedavisi, sistemik kalsitonin uygulaması, interferon alfa tedavisi gibi farmokolojik uygulamaların başarısı da kesin değildir ${ }^{21}$. Agresif lezyonlarda nüks gözlenmemesi için radikal cerrahi yöntemler tercih edilebilir. Bu durum fasiyal deformitelere neden olabilmektedir. Böyle bir durumda literatürde iliak greftle rekonstrüksiyon yapılan vakalar bildirilmiştir ${ }^{22-24}$. Hastada lezyon uzaklaştırıldıktan sonra fasiyal asimetri oluştuğu görülmüş ve defektin büyüklüğünden dolayı iliak greftle rekonstrüksüyon tercih edilmiştir.

\section{KAYNAKLAR}

1- Waldron CA: Bone pathology. In: Neville BW, Damm DD, Allen CM, Bouquot JE (eds), Oral and maxillofacial pathology. Philadelphia: Saunders, 1995; 453-5.

2- de Lange J, van den Akker HP, van den Berg H. Central giant cell granuloma of the jaw: a review of the literature with emphasis on therapy options. Oral Surg Oral Med Oral Pathol Oral Radiol Endod. 2007;104:603-15.

3- Whitaker $\mathrm{SB}$, Waldron $\mathrm{CA}$. Central giant cell lesions of the jaws. A clinical, radiologic, and histopathologic study. Oral Surg Oral Med Oral Pathol Oral Radiol Endod 1993; 75:199-208.

4- Kaffe I, Ardekian L, Taicher S, Littner MM, Buchner A. Radiologic features of central giant cell granuloma of the jaws. Oral Surg Oral Med Oral Pathol Oral Radiol Endod 1996; 81:720-6.

5- Rachmiel A, Emodi O, Sabo E, Aizenbud D, Peled $M$. Combined treatment of aggressive central giant cell granuloma in the lower jaw. J Craniomaxillofac Surg. 2012; 40:292-7.

6- Gungormus M, Akgul HM. Central giant cell granuloma of the jaws: a clinical and radiological study. J Contemp Dent Pract 2003; 4: 87-97.

7- Stavropoulos F, Katz J. Central giant cell granulomas: a systematic review of the radiographic characteristics with the addition of 20 new cases. Dentomaxillofac Radiol 2003; 31: 2137.

8- Yanik S, Aras MH. Management of central giant cell granuloma of mandible using intralesional corticosteroids: case report and review of literature. J Oral Maxillofac Surg. 2013; 71:721-2.

9- de Lange J, Rosenberg AJWP, van den Akker HP, Koole R, Wirds JJ, van den Berg $\mathrm{H}$. Treatment of central giant cell granuloma of the jaw with calcitonin. Int J Oral Maxillofac Surg 1999;28:3726.

10-Choi JW, Kraut RA. Management of central giant granuloma of mandible with intralesional triamcinolone injections: a case report. NY State Dent J. 2013;79:34-6.

11-O'Regan EM, Gibb DH, Odell EW. Rapid growth of giant cell granuloma in pregnancy treated with calcitonin. Oral Surg Oral Med Oral Pathol Oral Radiol Endod 2001; 92:532-8. 
12-Kurtz M, Mesa M, Alberto P. Treatment of a giant cell lesion of the mandible with intralesional glucocorticosteroids. Oral SurgOral Med Oral Pathol Oral Radiol Endod 2001; 91:636-7.

13-Nogueira RLM, Teixeira RC, Cavalcante RB, Ribeiro RA, Rabenhosrt SHB. Intralesional injection of triamcinolone hexacetonide as an alternative treatment for central giant-cell granuloma in 21 cases. Int. J. Oral Maxillofac Surg 2010: 9:120410.

14-Oda D. Alternative treatment for central giant cell "reparative" granuloma. Adv Anat Pathol 2003; 10:110.

15-Kruse-Lösler B, Diallo R, Gaertner C, Mischke KL, Joos $U$, Kleinheinz J. Central giant cell granuloma of the jaws: a clinical, radiologic, and histopathologic study of 26 cases. Oral Surg Oral Med Oral Pathol Oral Radiol Endod. 2006; 101:346-54.

16-Kaban LB, Troulis MJ, Ebb D, August M, Hornicek FJ, Dodson TB. Antiangiogenic therapy with interferon alpha for giant cell lesions of the jaws. J Oral Maxillofac Surg 2002; 60:1103-11.

17-Chuong R, Kaban LB, Kozakewich $\mathrm{H}$, Perez-Atayde $A$ : Central giant cell lesions of the jaws: a clinicopathologic study. J Oral Maxillofac Surg 1986; 44: 708-13.

18-Waldron CA, Shafer WG: The central giant cell reparative granuloma of the jaws. An analysis of 38 cases. Am J Clin Pathol 1966; 45: 437-47.

19-Rawashdeh MA, Bataineh AB, Al-Khateeb T: Longterm clinical and radiological outcomes of surgical management of central giant cell granuloma of the maxilla. Int J Oral Maxillofac Surg 2006; 35: 60-6.

20- de Lange J, van den Akker HP: Clinical and radiological features of central giant-cell lesions of the jaw. Oral Surg Oral Med Oral Path Oral Radiol Endod 2005; 99: 464-7.

21- Erdoğan Ö, Esen E, Yavuz M: Pharmacological and surgical interventions for the treatment of giant cell tumor of the mandible; report of a case after 5-year follow-up, Atatürk Üniv. Diş Hek. Fak. Derg. 2011; 21, 129-33.

22-Becelli R, Cerulli G, Gasparini G: Surgical and implantation reconstruction in a patient with giant cell central reparative granuloma. J Craniofac Surg 1998; 1: 45-7.
23-De Corso E, Politi M, Marchese MR, Pirronti T, Ricci $R$, Paludetti G: Advanced giant cell separative granuloma of the mandible: radiological features and surgical treatment. Acta Otorhinolaryngol Ital 2006; 26: 168-72.

24-Infante Cossı 'o $P$, Martinez de Fuentes $R$, Carranza Carranza A, Torres Lagares D, Gutierrez $\mathrm{Pe}$ 'rez JL: Recurrent central giant cell granuloma in the mandible: surgical treatment and dental implant restoration. Med Oral Pathol Oral Cir Bucal 2007; 12: 229-32.

\section{Yazışma Adresi}

Dt. Ahmet ALTAN

MKÜ Tayfur Sökmen Kampüsü

Diş Hekimliği Fakültesi

Ağız-Diş ve Çene Cerrahisi A.D

Antakya / HATAY

Tel: 05057013189

E-posta: dt.ahmetaltan@gmail.com 